\title{
Field note from \\ Pakistan floods: Preventing future flood disasters
}

\author{
Marcus Oxley \\ Chairman - Global Network of Civil Society Organisations for Disaster Reduction \\ marcus.oxley@globalnetwork-dr.org; \\ www.globalnetwork-dr.org
}

\section{ABSTRACT}

Unusually heavy monsoon rains in Northern Pakistan have caused disproportionate levels of extreme flooding and unprecedented flood losses across the entire Indus River basin. Extensive land use changes and environmental degradation in the uplands and lowlands of the river basin together with the construction of a "built environment" out of balance with the functioning, capacities, scale and limits of the local ecosystems have exposed millions of people to an increased risk of extreme flooding.

The catastrophic nature of the August flooding provides a unique opportunity to fundamentally change Pakistan's current socio-economic development path by incorporating disaster risk reduction and climate change measures into the post-disaster recovery process to rebuild a safer, more resilient nation.

In January 2005 one hundred and sixty-eight nations adopted the Hyogo Framework for Action (HFA) 2005-2015 to bring about a "substantial reduction in disaster losses" by 2015. Despite this global initiative a series of major disasters, including the recent flooding in Pakistan, all indicate that we are not on track to achieve the substantial reduction of disaster losses. The following fieldnote considers what can be done to accelerate progress towards implementation of the Hyogo Framework, drawing on insights and lessons learnt from the August flooding to understand how Pakistan and neighbouring countries can prevent a repeat of such catastrophic disasters in future years.

\section{KEYWORDS}

Pakistan; floods; August 2010; Hyogo Framework for Action (HFA); prevention; disaster risk reduction

\section{Introduction}

In January 2005 one hundred and sixty-eight nations, committed to bringing about a "substantial reduction in disaster losses by 2015" through the implementation of the Hyogo Framework for Action (HFA). In August 2010, at the midway stage of the HFA, the world has just witnessed what has been described as "the greatest humanitarian disaster in recent history" (Tweedie, 2010). The UN estimates 1,600 people died in the Pakistan floods with a staggering 20 million people affected - losing their homes, livelihoods and assets; the estimated cost of the flood damage is as high as $\$ 43$ billion and rising - representing a significant proportion of Pakistan's GDP and potentially threatening the country's political stability (Georgy, 2010; Hyder, 2010). The unprecedented scale of the Pakistan flooding in the wake of other recent 
major disasters including Haiti, China and Myanmar, and other smaller less dramatic events across Asia, Africa and the Americas, all serve to indicate the world's governments are not on track to achieve a substantial reduction in disaster losses by 2015 .

So what can be done to accelerate progress towards implementation of the Hyogo Framework and importantly what lessons can we draw from the Pakistan flooding to ensure the nation rebuilds itself in a way that can prevent a repetition of such catastrophic disasters in future years? The following fieldnote discusses why unusually heavy monsoon rains in northern Pakistan had such a devastating impact across the entire Indus River basin. It explores the relationship between people, the "natural environment" and the "built environment" and concludes with recommendations for the post-disaster recovery process that incorporate disaster risk reduction and climate change measures to achieve the rebuilding of a safer, more resilient nation.

\section{Unusually heavy rains leading to unprecedented flooding}

Seasonal flooding in Pakistan due to the annual monsoon rains is a regular and in many respects welcomed occurrence, albeit usually affecting a geographically limited area. By comparison the late July - August 2010 monsoon rains were unusually heavy in northern Pakistan; the region formally known as the Northwest Frontier Province recorded July rainfall totals of $180 \%$ above normal, with reports of 24-hour totals in excess of $300 \mathrm{~mm}$ on 29 July (Sayah, 2010; Slingo, 2010; Vastag, 2011; Pakmet, 2010). The heavy rains are thought to have been caused by a combination of strong winds (jet stream) high in the atmosphere over northern Eurasia serving to concentrate the monsoon over Northern Pakistan, together with "La Nina"-induced high sea surface temperatures and large amounts of moist air over the Indian Ocean. Whilst it is difficult to attribute specific weather events to human-induced global warming there is strong evidence from the Intergovernmental Panel on Climate Change and others that we are in a period of changing weather patterns characterised by an increase in the severity of extreme weather events, attributed in part to anthropogenic climate change (Cruz et al., 2007:488; Gray, 2010; Gronewold \& Climatewire, 2010; Walker Institute, 2011). It is expected that in future years heavy rainfalls as experienced in northern Pakistan will become more frequent across the region and other parts of the world.

Notwithstanding the intensity of the August 2010 rainfall, it is apparent that the unusually heavy rains in the north of the country caused disproportionate levels of extreme flooding throughout the Indus River basin, leading to unprecedented losses across virtually every province in the country. To understand why these rains had such a catastrophic impact it is necessary to consider how the land use in the river basin has changed in recent times.

\section{Land use changes in the Indus River basin}

The Indus River basin has long been considered one of the "cradles of civilisation" with evidence of human settlements going back over five millennia. Water management had been a key to the emergence of these early cities. Modern irrigation was introduced by the British around the 1850 's with the upgrading and extending of a network of irrigation and drainage canals (Hasan, 2010; Guisepi, 2007). Since that period, there have been substantial land use changes in the 
Indus valley and adjacent uplands to accommodate Pakistan's socio-economic development and the needs of a growing population (estimated population growth 2.2\% PA (World Bank, 2010:63). Extensive deforestation of natural forests in the upland catchment area for timber and fuel wood reduces the water-retention capacity of the forest eco-systems. This can increase surface water runoff and soil erosion, increasing the quantity, velocity and sediment load of the headwaters entering the river system. In turn this causes repeated landslides, damages riverine infrastructure and results in additional siltation of the downstream water channels.

In the lower reaches of the river basin there has been widespread clearing of shrub-lands and deforestation on the floodplains as well as extensive drainage of fertile wetlands to make way for expanding human settlements and agricultural cultivation. These land use changes and accompanying degradation of the natural environment continue along the entire river system culminating in the destruction of mangrove forests and fisheries of the Indus delta. Further research would be beneficial to better understand the political economy of land use changes amongst different user groups.

\section{Inappropriate built environment}

Little effort has gone into ensuring that the physical infrastructure is designed and constructed in balance with the capacity, scale and limits of the local ecosystems. The rapid expansion of formal and informal human settlements together with the construction of hydroelectric dams, barrages and an extensive system of roads, railways, bridges, flood protection embankments and drainage channels all serve to divert or constrain the natural pathways of the Indus and its tributaries, interrupting the natural ebb and flow of the monsoon flood waters.

Lack of sensitivity in the design and location of physical infrastructure in relation to the natural environment interferes with the important "regulating" function that the local eco-systems provide to the river system. A combination of increased inflows from the highlands and reduced water-carrying capacities of the heavily silted river channel, fertile wetlands and flood plains (now densely populated) exposes large numbers of people to increased risk from severe flooding during times of heavy rains. In the short-term, small localised flooding has been reduced and land protected for settlements and cultivation, but in the longer term the river system has little flexibility and redundancy to absorb heavy rainfalls which climate scientists predict will occur with increasing regularity.

The problem is further compounded by claims that much of the infrastructure was substandard in quality and inadequately maintained by government authorities (Gaadi, 2010; Gall, 2010; Lahiri-Dutt, 2010; Witte \& Khan, 2010). For example, in the recent flood event retaining walls and embankments failed. Canals and irrigation headworks have not been properly desilted and drainage channels, culverts and sluice gates are non-existent or else blocked with vegetation and debris.

\section{The importance of governance}

Good governance in the form of a capable, accountable and responsive government working together with civil society and at-risk communities is one of the single most important factors determining progress in reducing disaster risk. Governance is about the way states and people 
manage their affairs and is central to the solution to natural hazard risks (ISDR, 2009:97; UNDP, 1992). For example, the relationship between people, the natural and built environment is influenced by social, political and economic systems, and these in turn are mediated and regulated through the "governance" process.

As is often the case during a major disaster, the severity of a crisis can provide a major incentive to reform the system, serving to highlight mutual-dependencies and expose deficiencies in government development and disaster risk management policies and practices not readily apparent during "normal" times. Once the intensity of the monsoon rains became apparent it is possible that lives could have been saved and losses reduced had there been an effective community-based early warning and evacuation system that gave people time to sound the alarm and take evasive action - moving families, livestock and essential belongings to higher land. In terms of managing an effective emergency response, numerous agencies (including the United Nations) have highlighted the slowness and inadequacy of the state's response. There were shortages of basic emergency supplies and reported tensions between military and civilian authorities as to who had control of the emergency response programme.

The creation of the Pakistan National Disaster Management Authority following the 2005 Kashmir earthquake resulted in national and provincial-level policies and legislation being put in place in support of a more proactive approach to disaster risk management (Nguyen, 2010; UN, 2010; Aley, 2010). However, there remain significant gaps between government policies and local practices. Reports indicate policies are being weakened by a lack of resources and capacity at the provincial and district level to carry them out, notably good quality leadership, technical competencies and sufficient financial resources to invest in disaster risk reduction.

\section{Building community ownership and engaging local capacities}

On a positive note, Pakistan's citizens and locally-based organisations have been at the forefront of the emergency response with local authorities and civil society organisations working together from the outset of the flooding, taking a leading role in the search and rescue operations and providing essential supplies to people in hard-to-reach areas. Experience tells us the most effective way to increase societal levels of disaster preparedness is to enable local people to organise themselves and link them with the national disaster response mechanisms (Alam, 2008:3; ISDR, 2007). The most effective responses are those that build local ownership and strengthen local-level capacities as the first line of defence towards enhanced safety and protection. In a similar vein, affected people must be fully involved in the recovery process to ensure it is effective and sustainable in the longer term.

For many poor people dependent on agricultural-based livelihoods the recovery will be a long and difficult process; it is likely they have lost at least one year's crop production together with livelihoods and households assets. Food production levels may be significantly lowered for the next few years because of the combined effect of soil erosion, destroyed infrastructure and contaminated soils. Once immediate needs such as shelter, food, healthcare, water and sanitation have been met an extended period of support will be required to restore the necessary inputs and ensure food security from sowing through to harvest. Livestock too will have to be 
fed and looked after. The related problem of re-establishing land tenure is also likely to be a complex and difficult process.

Effective recovery will depend significantly on how quickly livelihoods and supporting infrastructure are restored. Fortunately the Pakistan authorities have considerable experience of organising and mobilising large-scale social protection and food security schemes through cash or food-for-work programmes. Such people-intensive approaches could be well suited to major infrastructure and environmental restoration work. For example, poor people whose livelihoods are dependent on natural resources have substantial local environmental knowledge and are well positioned to support national efforts to restore and enhance the functioning of the river basin ecosystems.

\section{Addressing underlying drivers of risk}

Notwithstanding the value of utilising local institutions and indigenous knowledge and capabilities, addressing the underlying political, social and macro-economic processes that put people at risk is beyond the remit and capacities of communities and local authorities. It will require a coordinated approach that takes into account the dynamic relationship between people, the natural and the built environments across the upland and lowland reaches of the river basin. This will necessitate a high degree of collaboration across a multitude of organisations at local, national, regional and international level involving the development of a comprehensive Indus River basin management strategy for Pakistan and neighbouring countries. The challenge lies in incentivising, designing and implementing a national recovery process which brings together different and sometimes conflicting interest groups, takes local context as the starting point, strengthens the capabilities of local people, and meets basic "unmet needs" whilst addressing pre-existing vulnerabilities. It will require the right technical advice, planning and management support; involve the connecting of local indigenous and external "scientific" knowledge; and importantly, building a sense of ownership, trust and mutuality between different actors to forge effective partnerships.

Executing a comprehensive recovery programme will undoubtedly require substantial international and national financial commitment to implement "at scale" bearing in mind that 20 million people were affected. Within the context of sustainable development, harmonised action on disaster risk reduction, climate mitigation and climate adaptation as well as livelihood resilience offer a possible way forward. For example, the restoration and maintaining of upland and lowland forests can reduce greenhouse gas emissions, support the restoration of the vital "regulating" function of forest ecosystems (essential to increase water retention and absorption capacities), whilst also serving as an essential adaptation strategy for local people whose livelihoods are dependent on natural resources against a future of climate change. The UN's Reducing Emissions from Deforestation and Forest Degradation (REDD) mechanism in developing countries potentially offers Pakistan a source of global funds for activities that could contribute towards both climate and disaster resilience (APPC, 2010). In using such funds the Pakistan government would have to consider the concepts of justice and equity to ensure the benefits of such programmes are widely shared amongst all stakeholders, particularly the most vulnerable groups. 
Perhaps the greatest need now is for a vision and belief by the people and government of Pakistan that it is possible to use the post-disaster recovery to rebuild a safer and more resilient society. In this respect perceptions are important because people's level of interest and ability to build safer communities is based on their knowledge, attitudes and experiences. Clearly the experience of the recent floods will have changed how people perceive disaster risk and in so doing open minds as to how to rebuild less disaster-prone communities and nations.

\section{Conclusions}

Pakistan's current socio-economic development path has created disaster risk by increasing people's exposure and vulnerability to extreme flooding during heavy monsoon rains. To prevent future catastrophic floods a fundamental change in the country's development path is needed that decouples exposure and vulnerability from economic growth and is more in harmony with the functioning, capacities and thresholds of the natural environment. With the benefit of hindsight it is apparent the catastrophic flooding in Pakistan was far from "natural" or an "act of God" but lay primarily in the hands of the Pakistan government who have the authority to manage its affairs in the economic, political and social spheres.

In this respect adopting a risk management approach in the post-disaster recovery offers a unique opportunity to build a safer more resilient society that provides for the basic protection and wellbeing of its citizens; in the short term the increased sense of awareness and interest in disaster risk reduction can provide the impetus to raise levels of disaster preparedness through developing forecasting, and early warning and evacuation systems. In the longer term, the greatest opportunities to prevent future disasters lie in harmonising actions on disaster risk reduction, climate change (mitigation and adaptation) and livelihood resilience to address the "underlying drivers" that configure risk in the first place.

To achieve this ideal the Pakistan government should lead in efforts to:

- Restore, conserve and enhance the capacities of the Indus River basin ecosystems and their services in both rural and urban areas (including linkages with relevant climate change actions).

- Protect and strengthen the resilience of rural livelihoods that depend on agriculture and other natural resources, including equitable access to common resources, productive assets (e.g. land, livestock, agricultural / business tools, financial services) and markets.

- Regulate land use and reconstruct a physical built environment that is sensitive to local (multi-hazard) risk conditions and in balance with the capacity, scale, thresholds and functioning of the natural environment and local eco-systems.

- Adopt a governance approach based on a capable, accountable and responsive government empowered by the decentralisation of authority and resources from central government and supportive of local initiatives in partnership with private sector and civil society organisations.

- Shift individual and societal perceptions, attitudes and behaviour towards a culture of 
safety and resilience through increased awareness and understanding of the interdependence of social, economic and ecological systems.

The main argument against adopting such an approach appears to be that it would slow down short-term economic growth (estimated $4.1 \%$ - 2009) considered essential to reduce poverty for a growing and already impoverished population, thereby increasing the risk of political instability. What the recent flooding has shown is that high levels of economic growth are ultimately not sustainable unless disaster risk reduction measures are incorporated into the development processes. In the words of Mahatma Gandhi (Phypers, 2009) - "speed is irrelevant if you are going in the wrong direction".

The August floods have inflicted a major setback to Pakistan's development. As the global climate changes, and Asian populations and economies continue to grow, such floods can and will happen again in Pakistan and neighbouring countries unless there is greater political commitment to tackle head-on the underlying drivers of disaster risk that are exposing millions of people to the type of suffering we are now witnessing. The extreme flooding in Pakistan has graphically illustrated the need to uphold one of the fundamental principles underlying the functioning of the Indus River basin and indeed the planet's biosphere, i.e. that social, economic and ecological systems on which millions of people depend are intrinsically interdependent the future of one depends on the wellbeing of the other.

Acknowledgement: This field note has been informed by a range of discussions and e-mail correspondence between Global Network members and interested parties, agency situation reports and flood assessments, expert observations and public statements. The opinions expressed are the author's and do not represent an agreed position of the Global Network membership.

\section{References}

ALAM, K. 2008. Flood disasters: learning from previous relief and recovery operations. Briefing paper on lessons learned from flooding. London: ALNAP/ProVention Consotrium. 16 p. Available at: http://www.proventionconsortium.org/themes/default/pdfs/ALNAP-ProVention_flood_lessons.pdf Date of access: 7 Mar. 2011.

ALEY, 2010. National Disaster Management Commission or a politically motivated parallel body? Available at: http://secularpakistan.wordpress.com/2010/08/19/national-disaster-management-commission-or-a-politically-motivated-parallel-body---by-aley/ Date of access: 7 Mar. 2011.

APPC (Associated Press of Pakistan Corporation). 2010. Pakistan for effective planning of global environment. Available at: http://app.com.pk/en_/index.php?option=com_content\&task=view\&id=123592\&Itemid=2 Date of access: 78 Mar. 2011. 
CRUZ, R.V., HARASAWA, H., LAL, M., WU, S., ANOKHIN, Y., PUNSALMAA, B., HONDA, Y., JAFARI, M., LI, C. \& HUU NINH, N. 2007. Asia. (In Parry, M.K., Canziani, J.P., Palutikof. O.F., Van der Linden, P.J. \& Hanson, C.E., eds. Climate change 2007: impacts, adaptation and vulnerability. Contribution of working group II to the Fourth Assessment Report of the Intergovernmental Panel on Climate Change. Cambridge: Cambridge University Press. p. 469-506.)

GAADI, M. 2010. The engineering failures behind the Pakistan floods. Available at: http://chimalaya. org/2010/08/20/the-engineering-failures-behind-the-pakistan-floods/ Date of access: 4 Mar. 2011.

GALL, C. 2010. Pakistan floods set back infrastructure by years. NY Times: 26 Aug. Available at: http://www.nytimes.com/2010/08/27/world/asia/27flood.html?_r=1 Date of access: 4 Mar. 2011.

GEORGY, M. 2011. Flood refugees threaten Pakistan's political stability. Available at: http://www. reuters.com/article/2010/09/22/us-pakistan-displaced-idUSTRE68L1CQ20100922 Date of access: 3 Mar. 2011.

GUISEPI, R.A. 2007. The Indus Valley and the genesis of South Asian civilization. Available at: http://history-world.org/indus_valley.htm Date of access: 4 Mar. 2011.

GRAY, L. 2010. Pakistan floods: climate change experts say global warming could be the cause. The Telegraph: 10 Aug. Available at: http://www.telegraph.co.uk/news/worldnews/asia/pakistan/7937269/ Pakistan-floods-Climate-change-experts-say-global-warming-could-be-the-cause.html Date of access: 3 Mar. 2011.

GRONEWOLD, N. \& CLIMATEWIRE. 2010. Is the flooding in Pakistan a climate change disaster? Scientific American: 18 Aug. Available at: http://www.scientificamerican.com/article.cfm?id=is-theflooding-in-pakist Date of access: 3 Mar. 2011.

HASAN, A. 2010. Pakistan - floods and after. Available at: http://www.iied.org/human-settlements/ key-issues/rural-urban-linkages/pakistan-floods-and-after Date of access: 4 Mar. 2011.

HYDER, K. 2010. As Pakistan drowns, its leaders fight. Available at: http://blogs.aljazeera.net/ asia/2010/09/01/pakistan-drowns-its-leaders-fight Date of access: 3 Mar. 2011.

ISDR (International Strategy for Disaster Reduction). 2007. Guidelines: national platforms for disaster risk reduction. Geneva: United Nations. 17 p. Available at: http://www.unisdr.org/eng/about_isdr/isdr-publications/03-guidelines-np-drr/eng-guidelines-np-drr.pdf Date of access: 7 Mar. 2011.

ISDR (International Strategy for Disaster Reduction). 2009. Global assessment report on disaster risk reduction. Geneva: United Nations. 207 p. Available at: http://www.preventionweb.net/english/hyogo/gar/report/index.php?id=9413 Date of access: 4 Mar. 2011.

LAHIRI-DUTT, K. 2010. Special essay: Pakistan floods. Available at: http://www.globalwaterforum. org/2010/09/06/special-essay-pakistan-floods/ Date of access: 4 Mar. 2011.

MAKIN, R. 2007. Ministerial conference on Disaster Risk Reduction, New Delhi, November. Available at: http://www.responsenet.org/show.detail.asp?id=3697 Date of access: 2 Mar. 2011.

NGUYEN, K. 2010. Q+A - UNDP expert discusses disaster risk reduction in Pakistan. Available at: http://www.reliefweb.int/rw/rwb.nsf/db900sid/MUMA-88B36A?OpenDocument Date of access: 7 Mar. 2011.

PAKMET (Pakistan Meteorological Department). 2010. Rainfall statement July-2010. Available at: 
http://www.pakmet.com.pk/FFD/index_files/rainfalljuly10.htm Date of access: 3 Mar. 2011.

PHYPERS, J. 2009. Quotes. Available at: http://www.solarhaven.org/Quotes.htm Date of access: 7 Mar. 2011.

SLINGO, J. 2010. Pakistan floods and extreme weather in August 2010. Available at: http://www. metoffice.gov.uk/news/in-depth/extreme-events Date of access: 3 Mar. 2011.

SAYAH, R. 2010. More than 400 people dead in Pakistan flooding. Available at: http://articles.cnn. com/2010-07-30/world/pakistan.floods_1_flood-victims-khyber-pakhtunkhwa-swat-valley? s=PM:WORLD Date of access: 3 Mar. 2011.

TWEEDIE, N. 2010. Pakistan floods: disaster is the worst in the UN's history. The Telegraph: 9 Aug. Available at: http://www.telegraph.co.uk/news/worldnews/asia/pakistan/7935485/Pakistanfloods-disaster-is-the-worst-in-the-UNs-history.html Date of access: 2 Mar. 2011.

UN (United Nations). 2010. General assembly calls for strengthened emergency relief to meet Pakistan's urgent needs after massive destrudtion caused by unprecedented, devastating floods. Available at: http:// www.un.org/News/Press/docs/2010/ga10969.doc.htm Date of access: 7 Mar. 2010.

UNDP (United Nations Development Programme). 1994. Governance for sustainable human development: a UNDP policy document. Available at: http://mirror.undp.org/magnet/policy/chapter $1 . h t m$ Date of access: 2011.

VASTAG, B. 2011. Pakistan floods highlight weather-data gaps. The Seattle Times: 19 Feb. Available at: http://seattletimes.nwsource.com/html/nationworld/2014266933_pakfloods20.

html?syndication=rss Date of access: 3 Mar. 2011.

WALKER INSTITUTE. 2011. Pakistan floods (late July/August 2011). Available at: http://www. walker-institute.ac.uk/news/news_pakistanfloods.htm Date of access: 3 Mar. 2011.

WITTE, G. \& KHAN, H.N. 2010. Pakistani government ramps up relief efforts in flooded northwest region. The Washington Post: 31 Jul. Available at: http://www.washingtonpost.com/wp-dyn/content/ article/2010/07/30/AR2010073000588.html Date of access: 4 Mar. 2011.

WORLD BANK. 2010. 2010 World Development Indicators. Washington: The World Bank. 464 p. Available at: http://data.worldbank.org/sites/default/files/wdi-final.pdf Date of access: 4 Mar. 2011. 